\title{
Städtisches Gemäldegalerie \\ - muzealna Miejska Galeria Malarstwa z okresu okupacji hitlerowskiej i jej historia*
}

Tajnowsza historia miasta wciąż kryje tajemnice - przedstawione tu fakświatowej nie były jednak trudno dostepne, a raczej wyparte. Warto przypomnieć ten ciekawy fragment dziejów miasta i historii muzealnictwa.

Galerie poznałam dzięki dokumentacji fotograficznej ze zbiorów Muzeum Okręgowego w Toruniu, do której sięgnęłam, poszukując zdjęć do referatu na konferencję Wokót zabytku. Tradycje i perspektywy postaw, poświęconą pamięci prof. Jerzego Remera (2009). Kolekcja okazała się niewyczerpanym - i niewykorzystanym - źródłem wiedzy dla wielu tematów, m.in. tytułowej galerii malarstwa, a także utraconych muzealiów i zabytków toruńskich, czyli przemilczanej/zapomnianej karty z dziejów polskiego muzealnictwa ${ }^{1}$. W odniesieniu do Städtisches Gemäldegalerie źródło to

* Referat pod tym tytułem, zaprezentowany podczas sesji naukowej Stare $i$,nowe” dziedzictwo Torunia (październik 2012 r.) oraz ten artykuł powstały na podstawie opracowania pt. Zagrabione, utracone muzealia toruńskie $i$ inne zabytki miejscowe. O stratach wojennych Muæeum w Toruniu, ale $i$ o powojennej ,planowej gospodarce murealiami, przygotowanego w Muzeum Okręgowym w Toruniu (2010-2011).

1 O tym szerzej w: Muzealna masa towarowa w toruńskim muzeum w czasach PRL-u $i$ relatywizm historyczny. O politycznym i ekonomicznym zagospodarowaniu muzealiów po II wojnie swratowej, referat na (drugiej) sesji naukowej Stare $i$,nowe” dziedzictwo Torunia, Bydgoszçy i regionu, luty 2015 r., złożony do druku. 
pozwoliło na określenie jej składu, a dalsze poszukiwania - na opis późniejszych losów galerii ${ }^{2}$. Fakt, że została ona pominięta w opracowaniu z okazji 150-lecia Muzeum (1861-2011) ${ }^{3}$ to swoiste zafałszowanie historii'.

Nietrudno zrozumieć, dlaczego okres okupacji hitlerowskiej w opisie dziejów Muzeum toruńskiego traktowano lakonicznie. Bez względu na oczywistą ocenę działań hitlerowców w Rzeczypospolitej w latach II wojny światowej nie można zapominać o niektórych faktach istotnych dla tej instytucji i dla miasta, mimo iż miały podłoże nacjonalistyczne i były realizowane przez okupanta.

Niemcy podjęli systematyczną akcję kopiowania dawnych widoków Torunia i portretów znanych lokalnych osobistości ${ }^{5}$. Wiedza o kopiowaniu dzieł malarskich pozwala wyciagać wnioski dotyczące dawnego zasobu $\mathrm{Mu}-$ zeum, np. skoro Heinrich Ruhoff namalował obrazy - Kram ze staryyzna w Ratuszu w Toruniu, Basz̨a Monstrancja według kompozycji Oscara Kauscha ${ }^{6}$ - w zbiorach znajdowały takie dzieła Kauscha; skoro Karl Hemmerlein namalował kopię portretu Samuela Thomasa Sömmerringa, zapewne pierwowzorem był wizerunek malarski ze zbiorów Muzeum. Niemcy celowo rozwijali archiwum fotografii (Bildarchiv), które obejmowało muzealia, Muzeum i miasto. Wielką liczbę fotografii wykonał Kurt Grimm, ale do-

2 O tworzeniu Städtisches Gemäldegalerie zob. P. Birecki, Sztuka w Torunin w okresie okupacji hitlerowskiej 1939-1945, Toruń 2011. Birecki cytuje m.in. moje ustalenia.

3150 lat Mu₹eum Okeregowego w Toruniu 1861-2011. Katalog wystany, red. A. Ziemlewska, Toruń 2011. Sa zaledwie jednozdaniowe wzmianki: s. 33 - o otwarciu Galerii, s. 40 - o wydaniu (sic) 171 obiektón z. działu sztuki w 1957 roku. Nie ma informacji o celowym usunięciu eksponatów z niemieckiej/hitlerowskiej Galerii.

4 W historii działu oświatowego Muzeum Okręgowego nie ma informacji nt. ideologicznych początków tych komórek organizacyjnych w muzeach; M. Sokołowska, 60-lecie dr̨iału edukacji w Muzeum Okregonym w Toruniu, „Rocznik Muzeum Okręgowego w Toruniu”, 18, 2009, s. 9-22.

5 Dzięki temu znamy m.in. weduty zniszczone podczas wojny... Zachowały się tylko niektóre kopie, pędzla Karla Hemmerleina, Heinricha Ruhoffa. Część kopii oddano po 1945 roku do Centralnej Składnicy Muzealnej.

6 O twórczości Hauptmanna (kapitana) Oscara Kauscha z 61. Infanterie-Regiment (regimentu piechoty) w Toruniu dziś wiadomo więcej dzięki odkryciu przez Sławomira Majocha jego szkicownika (1869/1870, 75 barwnych akwareli i rysunków tuszem, zbiory Westpreussisches Landesmuseum w Warendorf /d. Münster/). To najstarszy (po tzw. tece Steinera; zaginiona) zachowany album ikonografii Torunia. Majoch zaprezentował ten temat w WBP Książnicy Kopernikańskiej, w ramach cyklu Toruń miasto zabytków, w 2014 roku. 
konywano także zakupów. Wizerunki te publikowano w celach propagandowych, jako świadectwa odwiecznej niemieckości miasta ${ }^{7}$. Powołano do życia dział dokumentacji współczesnej (Zeitgeschichtliches Sammlung). To tutaj znalazł się cenny zespół zdjęć z uroczystości wmurowania kamienia węgielnego pod pomnik Mikołaja Kopernika, w 1943 roku.

Znacznie większą wartość przedstawiała - utracona wskutek powojennych decyzji władz Muzeum - Städtische Gemäldegalerie (Miejska Galeria Malarstwa). Tworzono ją od 1941 roku, z inicjatywy m.in. Adolfa Schwammbergera $^{8}$, ekspozycję otwarto 20 marca 1943 r. ${ }^{9}$ Liczyła ona ponad 100 obrazów (także grafika i rysunek), ważnych dla kształtowania niemieckiej kultury narodowej ${ }^{10}$. Bogusław Mansfeld stwierdził (2009), iż dzieła te na ogót dobrze ukasywaty gtowne tendencje artystyczne $i$ cenionych twórców ${ }^{11}$. To fakt, choć nie można odmówić słuszności i Halinie Załęskiej, która niemal pół wieku wcześniej pisała, iż kolekcja była zakupiona pręez okupanta w celu zniemczenia Muฉeum ${ }^{12}$, a zakup muzealiów był pomyślany tak, aby uystawriá w prayszłości same niemieckie obiekty ${ }^{13}$.

Były w tym zespole dzieła dobrej klasy, cenionych twórców: z kręgu monachijczyków ${ }^{14}$, jak m.in. Adolf Schreyer, Heinrich von Zügel, Friedrich

7 Zob. P. Birecki, Sztuka w Toruniu w okeresie okupacji..., jak w przyp. 2, s. 80 nn.

8 Dzięki dotarciu publikacji P. Bireckiego (Sztuka w Toruniu w okresie okupacji..., jak w przyp. 2), do Fürth, rodzinnego miasta Schwammbergera, jego wojenne dokonania w stosunku do toruńskich zabytków nareszcie zostały poznane i tam. Zob. też K. Kluczwajd, Internet, http:// toruniarnia.blogspot.com/2014/12/kulturalny-schwammberger-w-toruniu-i.html.

9 Eröffnung einer Städtischen Bildergalerie. 130 Meisterwercke der Malerei des 19. Jabrbunderts und der Gegenwart, „Thorner Freiheit“ 1943, z dn. 20 III 1943, s. 3.

10 Eröffnung einer Städtischen Bildergalerie..., jak w przyp. 9. Wspomniano o 130 dziełach malarskich dawnych i współczesnych. M. Niedzielska, Organizacja niemieckiego ṡycia kulturalnego w latach 1939-1945, w: Historia Torunia, t. III, cz. 2, red. M. Biskup, Toruń 2006, s. 659696, s. 668; B. Mansfeld, Sztuka od XIX do poczqtku XXI wieku, A. Błażejewska, K. Kluczwajd, B. Mansfeld, E. Pilecka, J. Tylicki, Historia sžtuki Torunia, Toruń 2009, s. 365-509, s. 433.

11 B. Mansfeld, Sztuka od XIX do poczatku XXI wieku, s. 433.

12 H. Załęska, Sprawozdania z dziatalności Muzeum w Toruniu za lata 1945-1961. Dżiat Sztuki, „Rocznik Muzeum w Toruniu” 1962, 1, z. 2, s. 9-51, s. 10.

${ }_{13}$ H. Załęska, Stulecie źbiorów muzealnych w Toruniu, „Rocznik Muzeum w Toruniu” 1962, 1, z. 1, s. 9-34, s. 27.

$14 \mathrm{O}$ dziełach monachijczyków na rynku antykwarycznym zob. m.in. Monachium $w$ Warsqawie. Wystawa malarstwa europejskiego XIX wieku, Dom Aukcyjny Desa Unicum, Warszawa, 
Voltz, Joseph Wenglein, Friedrich August von Kaulbach, także malarzy austriackich, czeskich i innych. W Galerii były prace m.in. Adolfa Menzela, Friedricha Wasmanna, Lovisa Korintha, Franza von Lenbacha, także artystów współczesnych, jak: Hans von Bartels, Wilhelm Busch, Albert von Keller, Moritz von Schwindt, Hans Thoma, Friedrich Wasmann, Max Slevogt, Walter Leistikow.

Obrazy Städtische Gemäldegalerie reprezentowały różne nurty i konwencje stylistyczne: od późnego klasycyzmu przez biedermeier (Josef Franz Danhauser, Ferdinand Georg Waldmüller), romantyzm (Eduard Gärtner [il. 1], Franz Seraph von Lenbach, Moritz von Schwind, Rudolf Friedrich Wasmann) i realizm (Eduard Friedrich Meyerheim, Karl Theodor von Piloty, Johann Wilhelm Preyer, Adolf Gustav Schlabitz, Anton Alexander von Werner), po impresjonizm (Adolf von Echtler, Ludwig Hans Fischer, Max Slevogt, Wilhelm Heinrich Trübner), symbolizm (Gabriel Cornelius Ritter von Max, Franz von Stuck, Hans Thoma [il. 2]) i secesję (Adolf Hengeler [il. 3], Walter Leistikow, Franz von Stuck, Ludwig von Zumbusch). Niewatpliwie ich doborem kierowały nie tylko kryteria artystyczne, ale cele ideologiczne (opór przeciw sztuce zdegenerowanej) oraz propagandowe ${ }^{15}$.

Pośród nabytków dominowały krajobrazy i portrety. Malarstwo pejzażowe reprezentowali m.in.: Oswald Achenbach, Heinrich Adam, Gregor von Bochmann -określany jako „malarz Bałtyku”, Ludwig Hans Fischer - który odbył liczne podróże, m.in do Norwegii, krajów Morza Śródziemnego, Azji, Friedrich Gauermann, Eduard Gärtner - słynący z dokumentowania widoków Berlina z jego architektonicznymi i technologicznymi „cudami”, a także Moskwy i Petersburga, Eduard Hildebrandt - który zwiedził niemal cały świat, Leistikow [il. 4], Benewitz von Löffen - urodzony w Toruniu, zafascynowany dziełami barbizończyków, Eduard Friedrich Meyerheim - autor m.in. krajobrazów z motywami gdańskimi, Carl Scherres [il. 5] znany z nastrojowych pejzaży z Prus Wschodnich i okolic Gdańska, Hans

15-30 lipca 2005 r., Internet, http://www.artbiznes.pl/jsp/artbiznes/wystawy.jsp;jsessioni$\mathrm{d}=9$ FCEC4DF388B089D68D4A8177139A201?Typ=detal\&IdWystawy=5208. Przykładowe ceny prac artystów, których obrazy znajdowały się w toruńskiej Städtische Gemäldegalerie: A. Schreyer, Polowanie, 1863 r. -400.000 USD (Nowy Jork, IV 2005); Joseph Wenglein, Pejzàे z rezek - 80.000 EUR (Monachium).

15 Zob. m.in. P. Birecki, Sztuka w Toruniu w okresie okupacij..., s. 80-81. 
Thoma - uznawany za jednego z najoryginalniejszych artystów niemieckich 2. połowy XIX w., najbardziej ceniony właśnie za pejzaże, Paul Weber - inspirowany wpływami barbizończyków, Joseph Wenglein - wybitny pejzażysta monachijski. Specjalistami w dziedzinie mariny byli: Hans von Bartels, Gregor von Bochmann, Eduard Hildebrandt.

W grupie portretów były dzieła twórców równie wysokiej klasy, byli wśród nich m.in. Friedrich von Amerling [il. 6] - nadworny malarz Habsburgów, autor około tysiąca portretów, którego twórczość dziś uznawana jest za jedno z najistotniejszych osiagnięć sztuki portretowej, Albert von Keller, Franz Seraph von Lenbach - malujący wizerunki przedstawicieli elity, Max Slevogt, Ferdinand Georg Waldmüller [il. 7] - jeden z najlepszych portrecistów czasów biedermeieru w Austrii. W galerii Schwammbergera znalazły się również dwa dobrej klasy portrety władców: Wilhelma I i Fryderyka III, autorstwa Emila Neide, profesora Akademii w Królewcu ${ }^{16}$.

Malarstwo rodzajowe reprezentowali m.in. Franz von Defregger i Eduard Theodor Ritter von Grützner [il. 8] - należący do najlepszych malarzy rodzajowych w Monachium 2. połowy XIX w., także Adolf Gustav Schlabitz, a martwą naturę - Grützner, Adam Ludwig Kuntz, Johann Wilhelm Preyer. Obrazy o tematyce animalistycznej wyszły spod pędzla: Emila Adama - z artystycznej rodziny Adamów (jego brat Heinrich był pejzażysta), Friedricha Gauermanna - wiele jego dzieł sztychowano, osiagały one wysokie ceny, obu Voltzów (Ludwiga Gustava i Friedricha Johanna). Mniej liczna była grupa prac o tematyce historycznej, warto jednak wspomnieć nazwiska Leopolda Güterbocka, Karla Theodora von Piloty'ego, Antona Alexandera von Wernera - jednego z najbardziej cenionych niemieckich malarzy historycznych, ulubieńca cesarza Wilhelma II, krytykowanego jednak przez postępowe kręgi artystyczne za polityczne zaangażowanie, także batalisty Wilhelma Camphausena [il. 9], wybitnego przedstawiciela narodowego malarstwa historycznego.

Zawiadujący toruńską kultura Adolf Schwammberger w sprawozdaniach z działalności Wydziału Kultury pisał (I 1942), że zakupiono 60 rysunków, ponad 300 rycin i ponad 80 obrazów malarzy wschodnio-nie-

\footnotetext{
16 B. Mansfeld, Sztuka od XIX do poczatku XXI wieku, s. 434. Te dwa portrety, niezachowane w zbiorach Muzeum, nie maja dokumentacji fotograficznej.
} 
mieckich, reprezentatywnych dla sztuki XIX w. Wymienił m.in. następujace nazwiska: Friedrich August von Kaulbach, Franz Seraph von Lenbach, Moritz von Schwind, Franz von Defregger, Watzmann (zapewne Rudolf Friedrich Wasmann), Walter Leistikow, Bennewitz von Löfen, Friedrich Wilhelm Völcker, Daniel Chodowiecki, Eduard Hildebrandt, Hans Thoma, Ludwig von Zumbusch, Joseph Wenglein ${ }^{17}$. W 1942 roku zbiór rysunków i rycin Daniela Chodowieckiego powiększył się do ponad tysiąca sztuk. Wcześniej (przed 1939 r.) Muzeum posiadało 127 rycin tego autora, z darowizny Walerego Amrogowicza dla Towarzystwa Naukowego ${ }^{18}$.

W kwestii wątków narodowościowych w kolekcjonerstwie i wystawiennictwie należy wspomnieć, że toruński Kunstverein (zał. 1941) planował organizowanie ekspozycji, co ze względu na działania wojenne nie było łatwe. W latach 1941 i 1942 odbyły się wystawy gwiazdkowe (Weibnachst-Kunstausstellung des Kunstverein Thorn), na których pokazano prace miejscowych artystów. W ich gronie znalazły się m.in. Anne Schulze-Köper i jej siostra Erika Schulze ${ }^{19}$, które w latach 30. XX w. związane były z Konfraternią Artystów ${ }^{20}$ (sic).

Jakie były powojenne losy toruńskiej Städtisches Gemäldegalerie? Ten fragment dziejów polskiego muzealnictwa, a jednocześnie historia zgodna z zasadami PRL-owskiej planowej gospodarki... muzealną masą towaro$w_{a}^{21}$ dziś zadziwia. Niemal w całości galerię z Muzeum usunięto, podobnie jak to działo się w całej Polsce z ministerialnego nakazu². Trudno zaak-

17 Archiwum Państwowe w Toruniu (dalej: APT), Akta Miasta Torunia (dalej: AmT) 1939-1945, E.735, Sprawozdania z działalności Wydziału Kultury..., rkps Schwammbergera, brudnopis sprawozdania z 27.01.1942, s. 89, 157.

18 H. Makowiecka, (Sprawozdania) Driat grafiki, „Rocznik Muzeum w Toruniu”, 1962, 1, z. 2, s. 52; M. Niedzielska, Organizacja niemieckiego życia kulturalnego...1945, s. 668. O kolekcji Amrogowicza: A. Musiałowski, Walery C. Amrogowicz, (1863-1931). Pasja sycia. Kolekecja numizmatyczna, Torú 2004.

19 APT, AmT 1939-1945: E.837, s. 61-69, Weibnachst-Kunstausstellung des Kunstverein Thorn, 1942; E.837, s. 59-60; Weihnachst-Kunstausstellung des Kunstverein Thorn), b.d. O Kunstverein i wystawach w toruńskim Muzeum w okresie okupacji zob. też P. Birecki, Sztuka w Toruniu w okresie okupacji..., s. 32-33, 108-113.

20 B. Mansfeld, Sztuka od XIX do poczqteu XXI wieku, s. 441-442. Konfraternia Artystów była stowarzyszeniem o polskim i narodowym charakterze.

21 Zob. K. Kluczwajd, Muzealna masa towarowa...

22 Tamże. 
ceptować przesłanki ówczesnych decyzji o upłynnianiu określonych grup muzealiów - aż po rok 1958 (sic), choć uzasadniała je wszechobecna ideologia i jej pochodne: centralne sterowanie i system nakazowy.

Muzeum toruńskie w latach 1947-1958 oddało zabytki, także te ze Städtisches Gemäldegalerie, do różnych instytucji. Były to: Centralna Składnica Muzealna Ministerstwa Kultury i Sztuki i Państwowe Przedsiębiorstwo Wydzielone Desa, które zabytki te sprzedawały (dochód do dyspozycji Ministerstwa Kultury i Sztuki lub Desy), Wydział Sztuk Pięknych UMK ${ }^{23}$ oraz miejscowy teatr, Stowarzyszenia Architektów Polskich. Tylko w przypadku Żydowskiego Instytutu Historycznego był to przekaz celowy, bo do instytucji o charakterze muzealnym.

Jeden z usuniętych obrazów - Adolfa Gustava Schlabitza Tyrolcasycy/ / Bawarcsycy [il. 10], odnalazłam (I 2009) jako ofertę Sotheby's, z lat 2007 i $2008^{24}$. Jak obraz znalazł się zagranicą? Zapewne Centralna Składnica Muzealna przekazała dzieło do Desy, a ta mogła je legalnie sprzedać. $\mathrm{Na}$ liście muzealiów oddanych jest też obraz, który wciąż pozostaje w zbiorach Muzeum toruńskiego - Przed drzwiami domu Maxa Kaufmanna. Jak to możliwe? W ramach obowiązującej procedury spisy muzealiów wyselekcjonowanych odgórnie kontrolowano i ostatecznie nie wszystkie obiekty byky przejmowane.

Wróćmy do losów Galerii. W wyborze obiektów do uplynnienia czasem trudno dopatrzeć się konsekwencji, czego przykładem mogą być prace Karla Hemmerleina. Większość z nich oddano (do Desy i Składnicy Muzealnej), pzostawiono - jednak tylko niektóre - kopie portretów znanych torunian: Hermanna Balka, Mikołaja Kopernika, Heinricha Strobanda i kilka innych kompozycji (np. Portret żony artysty, Akt) [il. 11]. Pozbywano się obiektów o tematyce zaangażowanej ideologicznie po stronie niedawnego wroga, jak Hemmerleina widok ratusza, który to obraz stanowił dar okupacyjnych władz miasta dla ministra spraw wewnętrznych III Rzeszy (Reichsmi-

23 Niektóre obiekty jako depozyt. Archiwum Muzeum Okręgowego w Toruniu, 3/134, Dokumentacja depozytowa muzealiów Muzeum Pomorskiego w Toruniu 1950-1951, k. 35.

24 Aukcje Sotheby's z 24.04.2007, 4.08.2007, 21.05.2008, zob. Internet, www.arcadja.com/ auctions/en/schlabitz_adolf_gustav/artist/25945/. W sierpniu 1945 roku obraz Tyrolcaycy, okragły na desce, średn. $100 \mathrm{~cm}$, w grupie 59 obiektów wrócił z Wyrzyska... (APT, Akta Muzeum Miejskiego, 2). 
nister) Dr. Wilhelma Fricka, z okazji jego wizyty w mieście 21 czerwca 1942 roku [il. 12]. Zaangażowanych choćby w odległej przeszłości, jak np. „portrety Wilhelmów” pędzla Theodora Knorra, którego kompozycje o charakterze neutralnym światopoglądowo pozostawiono ${ }^{25}$. Podział kopii sławnych torunian pędzla Hemmerleina na te do zaakceptowania (jak wyżej) i te do oddania, ukazuje, że kryteria oceny były płynne. Pozostawiono kopię wizerunku Strobanda, ale innego zasłużonego burmistrza Torunia, Gottlieba Melliena, już nie. Usunięto też (współczesny) portret syna dyrektora Wohlfeila - czy dlatego, że Hemmerlein oprócz kopii dawnych portretów malował wizerunki współczesnych, jak np. Führera w reprezentacyjnej wersji (dla Dworu Artusa), jako budowniczego Trzeciej Rzeszy? Trudno dociec, dlaczego Muzeum pozbyło się toruńskich wedut, np. Adama Bernharda, Hansa Gebeleina [il. 13].

Nawet jeśli zabytki toruńskie - muzealia, ale i inne, jak np. renesansowy stół intarsjowany z Ratusza Staromiejskiego ${ }^{26}$, sprzęty z miejscowej synagogi, galeria malarstwa niemieckiego XIX-XX w. - dziś są zaginione, znajdują się w innym miejscu lub ich losy są nieznane, ważna jest wiedza o nich oraz właściwe ich miejsce w historycznym obrazie miasta i muzeum jako miejskiej instytucji kultury. Wykorzystanie tych dzieł jako źródeł jest równie ważne, jak wyciagnięcie z ich losów wniosków szerszej natury: na temat dziejów Polski, Torunia i jego lokalnej społeczności, muzealnictwa i jego przemian - uwikłania w ideologię, zmiany celów i priorytetów, otwarcia na świat.

25 W Muzeum pozostały obrazy: Portret Napoleona I Bonaparte, Kobieta z. koszem jaj, portrety.

26 Ten wysokiej klasy stół z rozkładanym blatem, z około 1600 r., został odkryty niedawno, w handlu antykwarycznym w Niemczech (2010 r., informacja od prof. Michała Woźniaka). Wczesny czas powstania intarsji, jej klasa artystyczna i hipotetyczne wykonanie mebla w Toruniu (?) zmieniają obraz meblarstwa toruńskiego okresu nowożytnego.

Przed rokiem 1903 mebel był w kolekcji Friedricha Lippmanna, kuratora w Muzeum Sztuki w Wiedniu, dyrektora Królewskiego Gabinetu Rycin w Berlinie. W 1912 roku zabytek odnotowano na aukcji w Berlinie (Rudolf Lepcke's Kunst Auctions Haus. Katalog Nr 48, Berlin 1912, s. 37 - drewno dębowe, węgierski jesion i klon, wym.: wys. 79 cm, płyta 141 $/ 253 / \times 110 \mathrm{~cm}$. Blat ze scenami figuralnymi w technice intarsji, m.in. owalne kartusze z personifikacjami: 12 miesięcy, 4 żywioły, 4 części świata). Zabytek wzmiankowany w: Otto von Falke, Deutsche Möbel des Mittelalters und der Renaissance, Stuttgart 1924, s. 183. 
Artykuł ten, oprócz dostarczenia nowych informacji na temat utraconych muzealiów toruńskich, ma na celu ukazanie zapomnianej karty z dziejów toruńskich instytucji muzealnych, przeobrażających się dynamicznie w XX w., których dzisiejsze Muzeum Okręgowe jest spadkobierca. To także okazja do refleksji natury ogólnej. Minęło niewiele lat, a zbiory muzealne były przewartościowywane kilkakrotnie: przez hitlerowskiego okupanta, w duchu ,jedynie słusznego” socjalizmu, wreszcie - wedle kryteriów obiektywnych: naukowych, regionalnych itd. Minęło wystarczająco wiele lat, aby o tym mówić - zarówno o podstawach i intencjach dawnych praktyk muzealnych, jak i o ich konkretnych i wymiernych skutkach. W odniesieniu do muzeów i w Toruniu i w Polsce.

\section{Summary}

\section{Städtisches Gemäldegalerie \\ - the museum's Municipal Gallery of Painting during the Second World War and its history}

The presented facts concerning the museum's Städtisches Gemäldegalerie during the Second World War are one of the rather willingly forgotten parts of the history of Torun and the local museum. This period is closely connected with the Polish People's Republic principles of centrally planned economy and disposing of the unwanted exhibits, i.e. devoid of artistic and/or historical values - because of such orders from the Ministry.

Städtisches Gemäldegalerie, founded in the years 1941-1943, was almost wholly transferred by the Museum of Torun in the years 1957-1958 (sic) - to the Central Museum Storehouse of the Ministry of Culture and National Heritage and to PPW Works of Art and Antiques Desa. The exhibits were given away without any remuneration, thus undermining and reducing the collection of exhibits of the museum.

Old photographs belonging to the museum made it possible to get to know the contents and the quality of the lost exhibits. They did not attract anybody's attention for several decades... Therefore not surprisingly, a publication commemorating the $150^{\text {th }}$ anniversary of the museum (1861-2011) did not contain any mention of the Gallery, which is a serious omission.

Städtisches Gemäldegalerie contained over 100 paintings (including graphics and drawings), important for the German national heritage and representing the 
most prominent artistic notions of the second half of the $19^{\text {th }}$ and the first third of the $20^{\text {th }}$ century. The works were chosen based not only on their artistic merit, but also on their ideological and propaganda message (e.g. against degenerate art). The authors of the works of art were members of the Munich School (Adolf Schreyer, Heinrich von Zügel, Friedrich Voltz, Joseph Wenglein, Friedrich August von Kaulbach), Austrian, Czech and other painters. Not only the works of Adolf Menzel, Friedrich Wasmann, Lovis Korinth, Franz von Lenbach formed parts of the collection, but also works of contemporary authors, such as Hans von Bartels, Wilhelm Busch, Albert von Keller, Moritz von Schwindt, Hans Thoma, Friedrich Wasmann, Max Slevogt, Walter Leistikow.

Nowadays some of these works of art were tracked down, usually when enlisted during Polish and international auctions of art.

Apart from presenting the information about the lost exhibits of the museum, the article aims at inducing some general reflection. Over the years the museum's exhibits were repeatedly re-assessed: by the German occupants, according to the principles of socialism and finally objectively: according to the scientific, artistic and regional criteria. Enough time has passed to discuss these practices in detail - both their grounds, intentions and aims behind them and their still visible results and consequences. For they did not concern only the museum in Torun, but those in the whole Poland and thus need to be analysed in a wider perspective. 


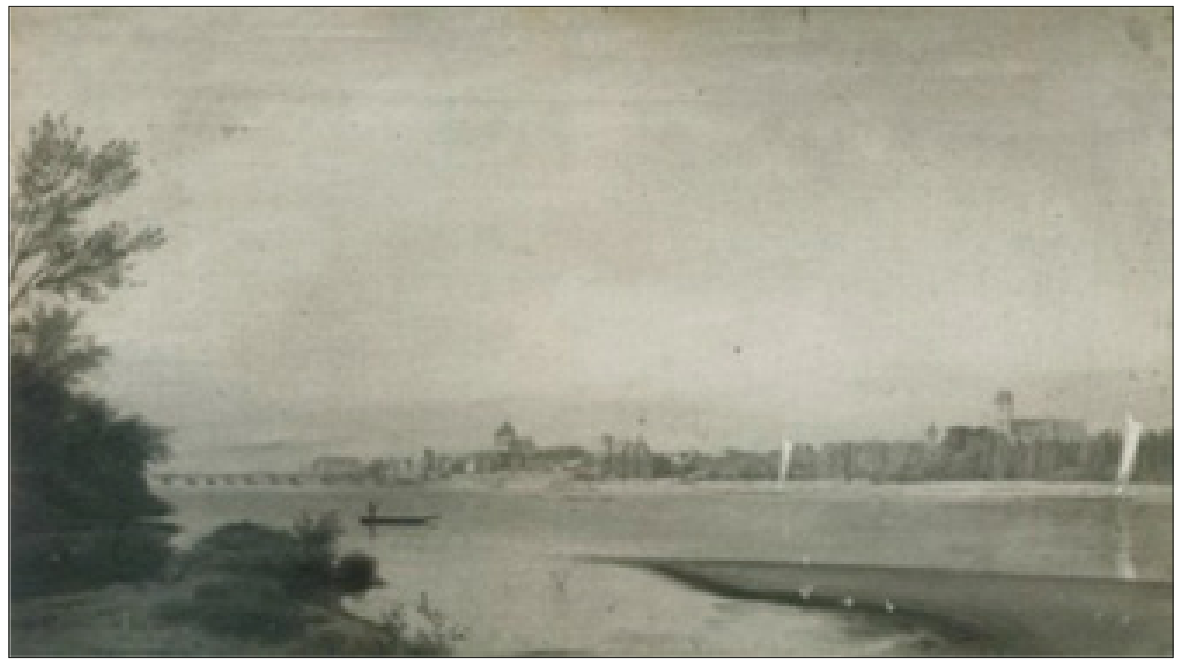

Il. 1. Johann Philippe Eduard Gärtner (1801-1877), Panorama Torunia (od południowego wschodu), 1850. Fot. Kurt Grimm, 1943. Fot. Muzeum Okręgowe w Toruniu 


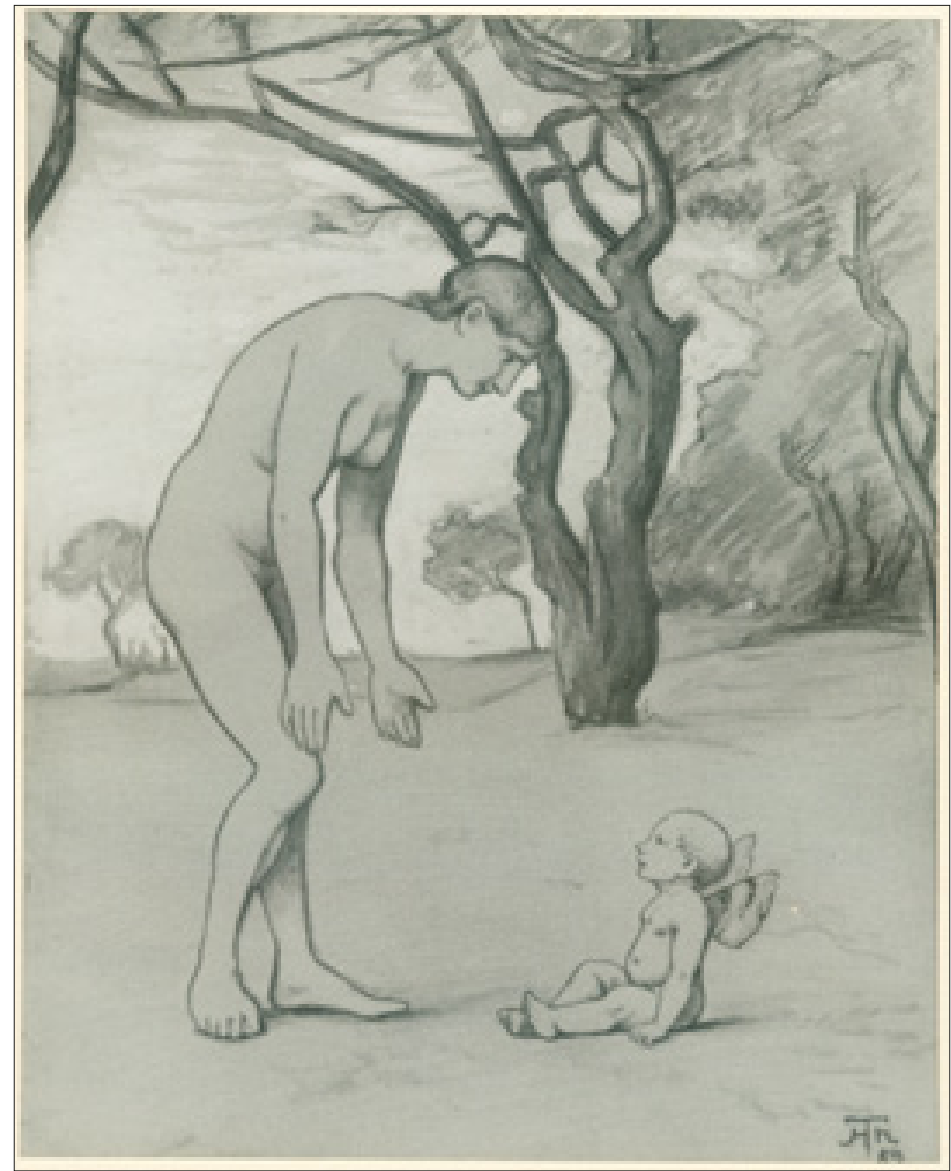

Il. 2. Hans Thoma (1839-1924), Komposycja symbolična, 1889, sygn. Fot. Kurt Grimm, 1942. Fot. Muzeum Okręgowe w Toruniu 


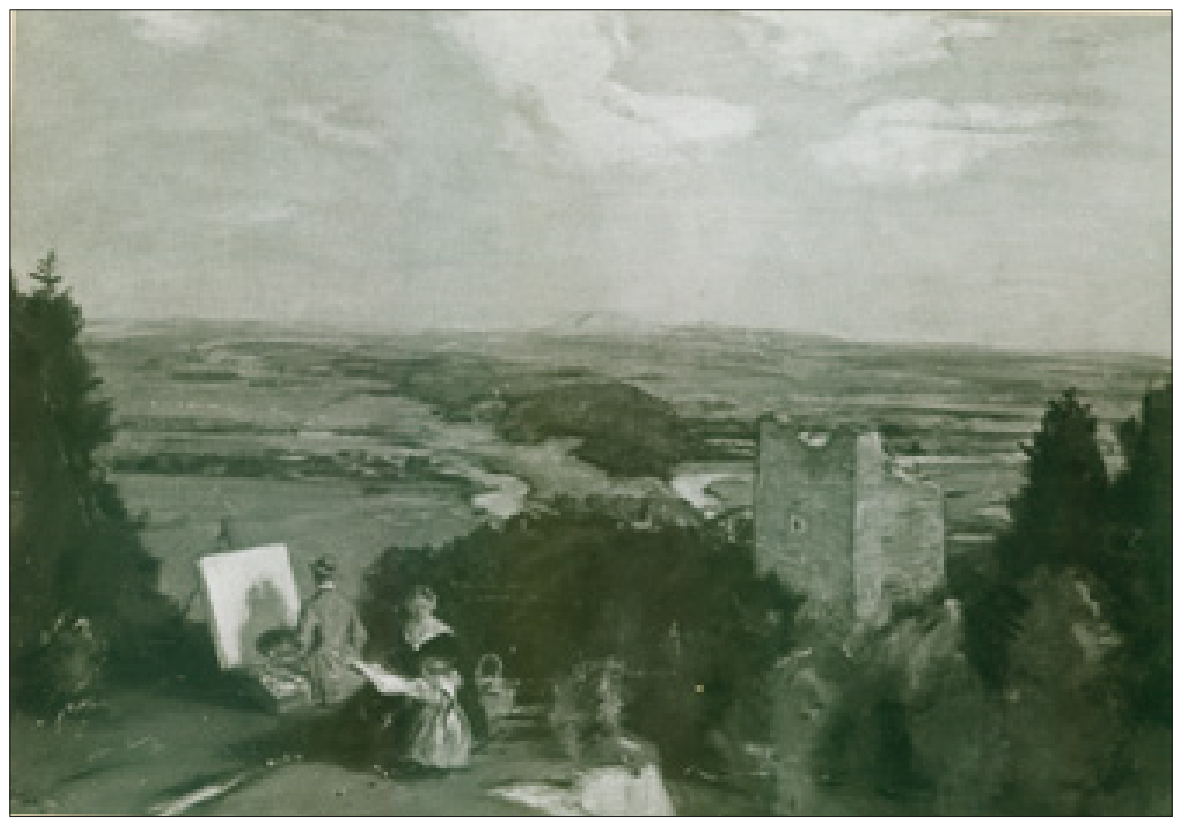

Il. 3. Adolf Hengeler (1863-1927), Pejzaそ. Fot. Kurt Grimm, 1942.

Fot. Muzeum Okręgowe w Toruniu

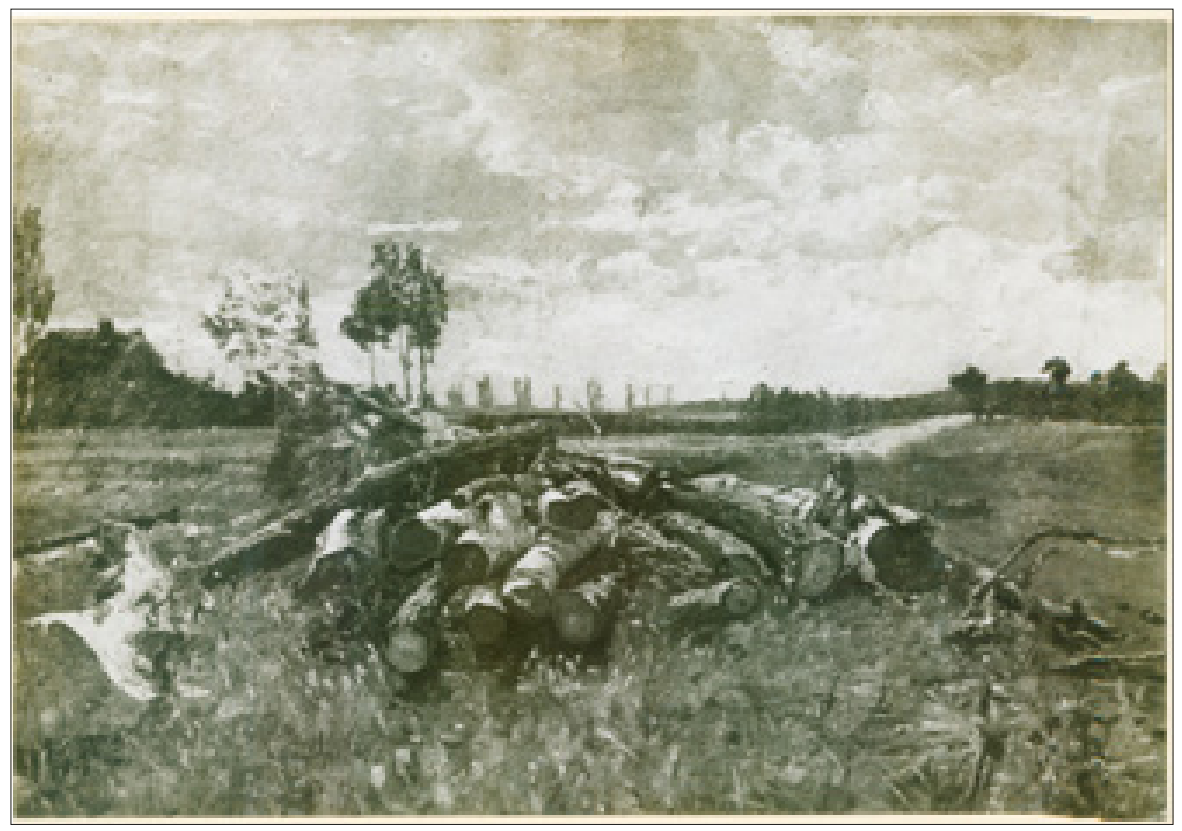

Il. 4. Walter Leistikow (1865-1908), Pejza\%: Fot. Kurt Grimm, 1942.

Fot. Muzeum Okręgowe w Toruniu 


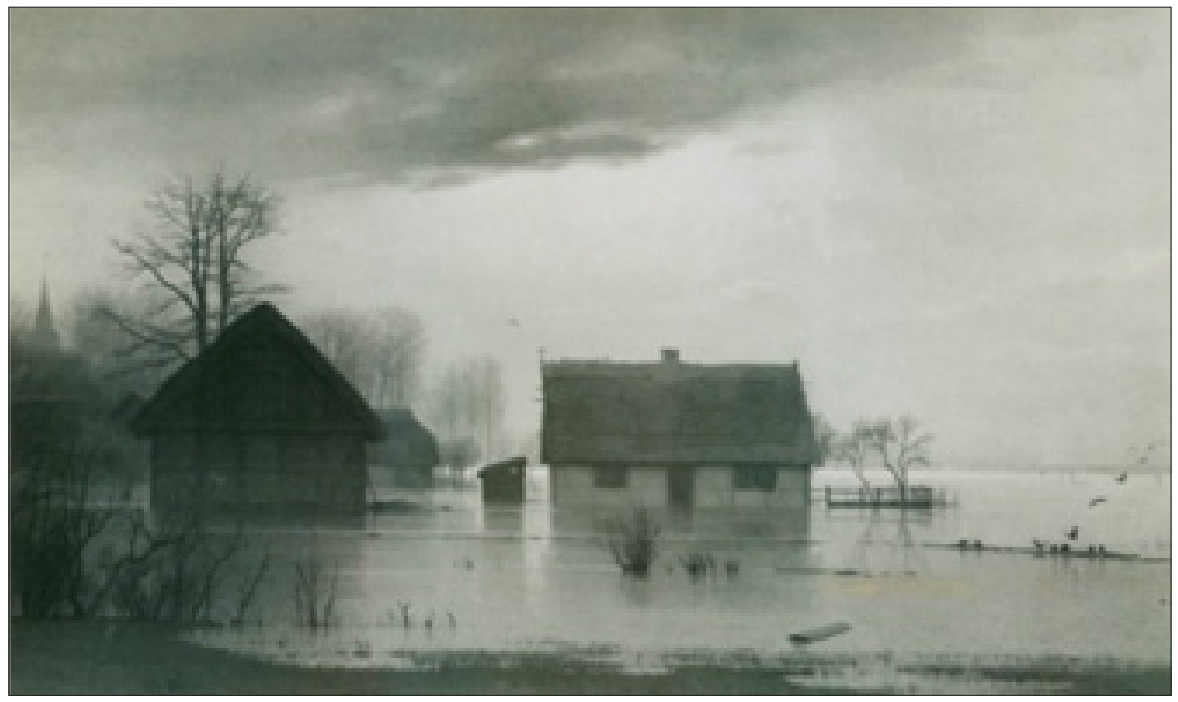

Il. 5 Carl Scherres (1833-1923), Powód乏́ / Po burzy. Fot. Kurt Grimm, 1942. Fot. Muzeum Okręgowe w Toruniu. Obraz odnotowany na aukcji Domu Aukcyjnego Agra Art (31.000zł), w październiku 2000 roku, [za: Internet, http://www.agraart.pl/cgi-bin/obiekt. cgi?act $=1 \& q \mathrm{t}=1271128997 \& \mathrm{nr}=1573$ ] 


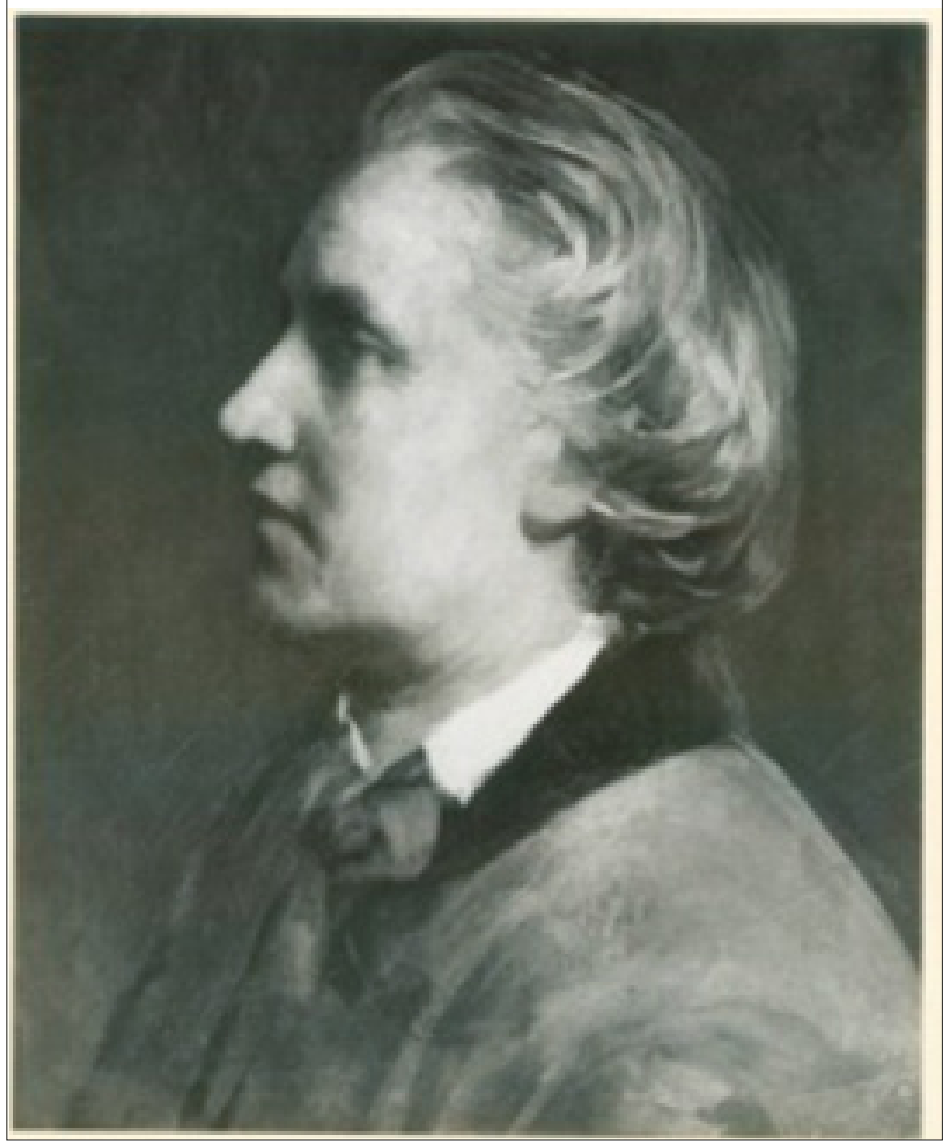

Il. 6. Friedrich von Amerling (1803-1887), Portret mę̇сryyzny. Fot. Kurt Grimm, 1943.

Fot. Muzeum Okręgowe w Toruniu 


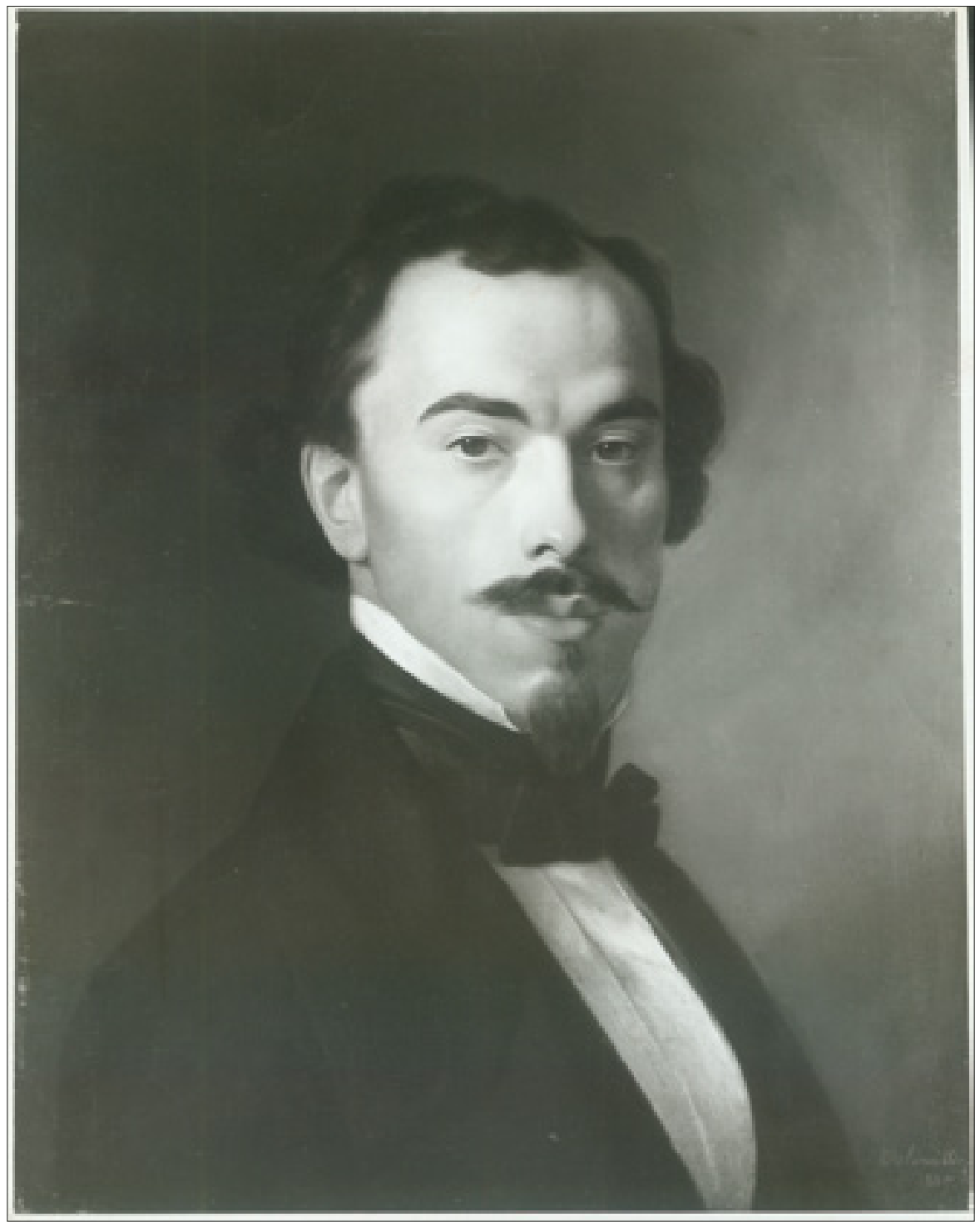

Il. 7. Ferdinand Georg Waldmüller (1793-1865), Portret mę̇́çyzny, 1847, sygn. Fot. Kurt Grimm, 1939-1945.

Fot. Muzeum Okręgowe w Toruniu 


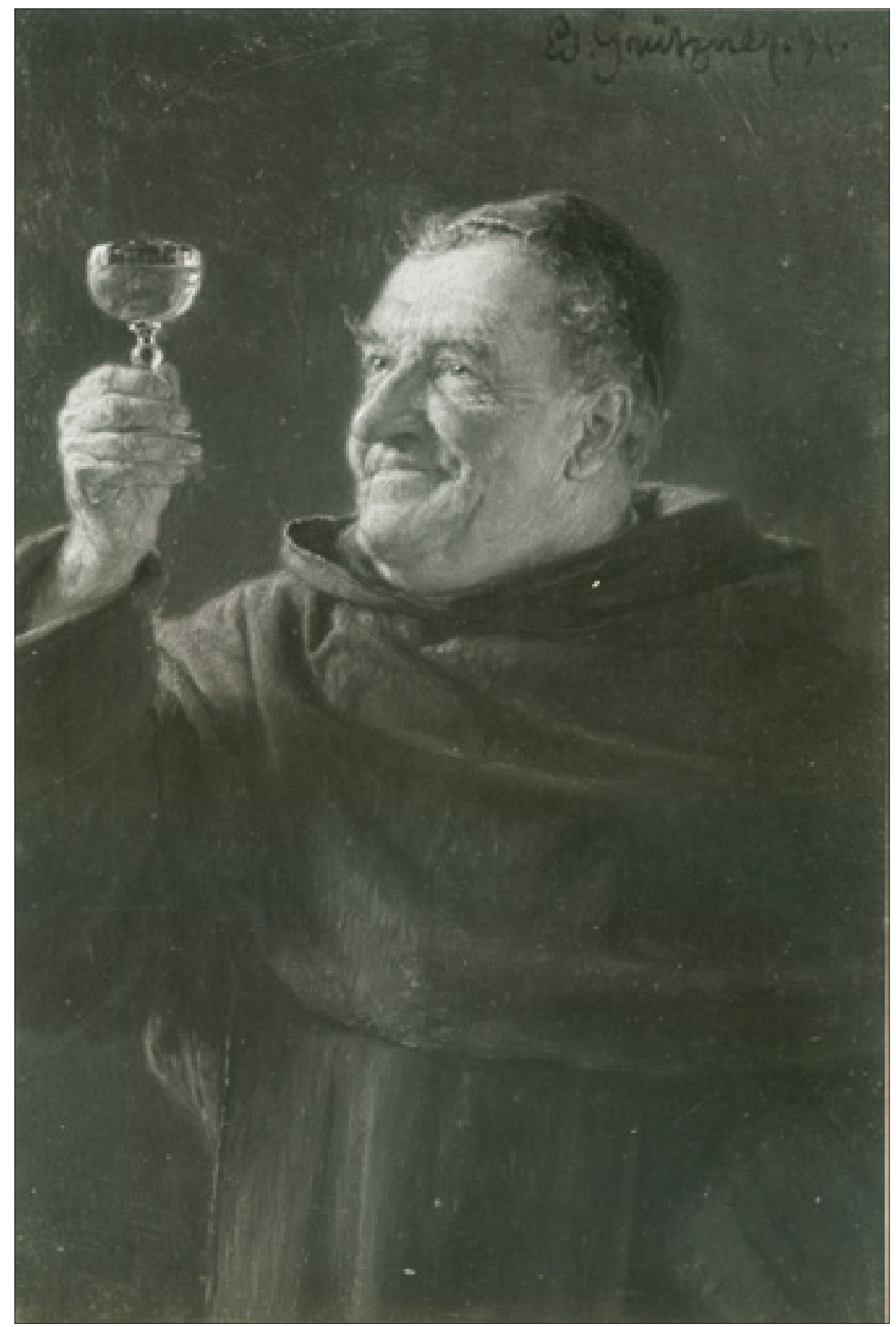

Il. 8 Eduard Theodor Ritter von Grützner (1846-1925), Próba wina. Fot. Kurt Grimm, 1942.

Fot. Muzeum Okręgowe w Toruniu.

Analogiczne kompozycje sprzedano w 2009 roku w Domu Aukcyjnym Hampel za 16.000-15.000 Euro, [za: Internet, http://www.hampel-auctions.com/de/archive-artists/g/727.html/] 
[260]

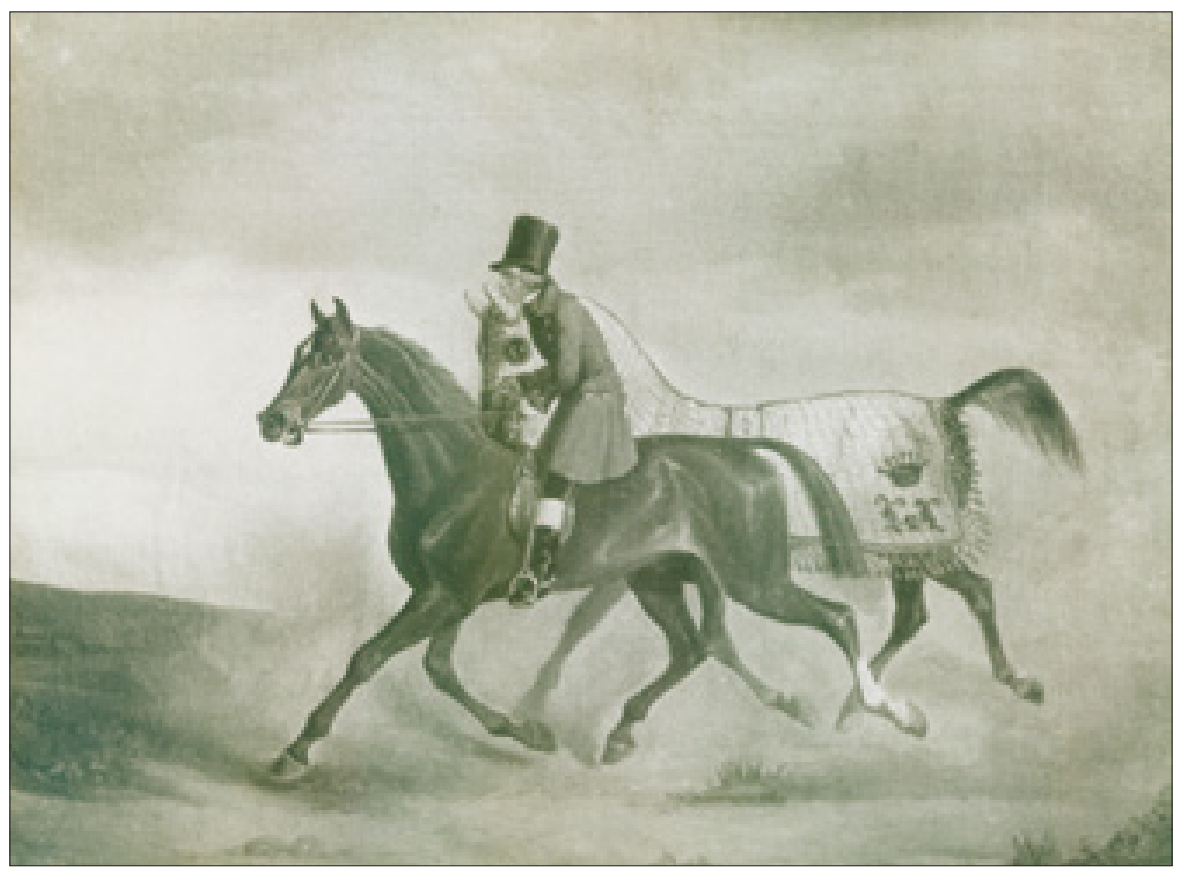

Il. 9. Wilhelm Camphausen (1818-1885), Ję́dziece. Fot. Kurt Grimm, 1942. Fot. Muzeum Okręgowe w Toruniu 


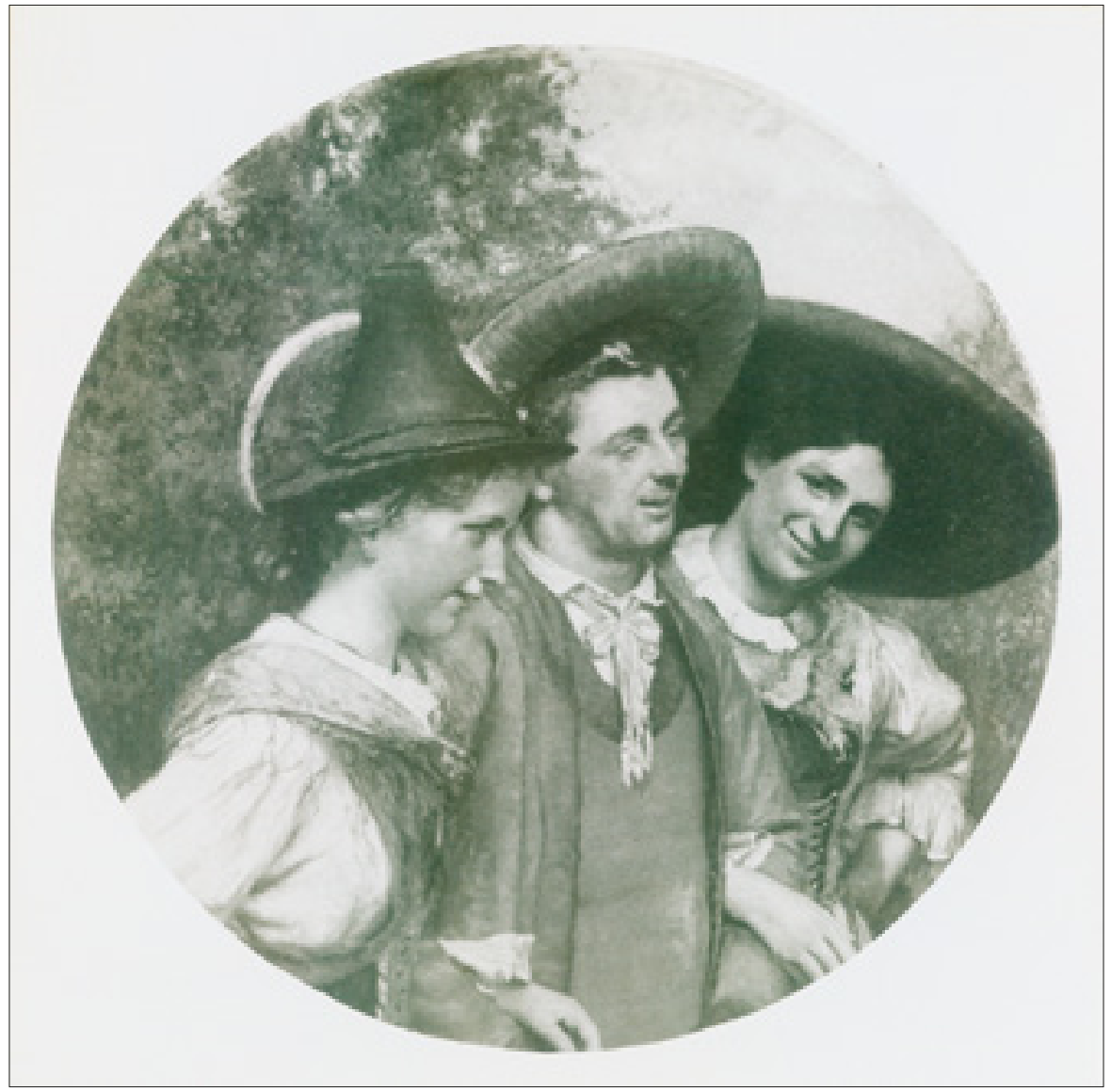

Il. 10 Adolf Gustav Schlabitz (1854-1943), Tyrolcsycy / Bawarcsycy, 1918, sygn. Fot. Kurt Grimm, 1942.

Fot. Muzeum Okręgowe w Toruniu.

Obraz odnotowany na aukcji w Sotheby's, w kwietniu 2007 roku, [za: Internet, http:// www.artvalue.com/auctionresult--schlabitz-adolf-gustav-1854-19-a-merry-bavariancompany-1530773.htm] 


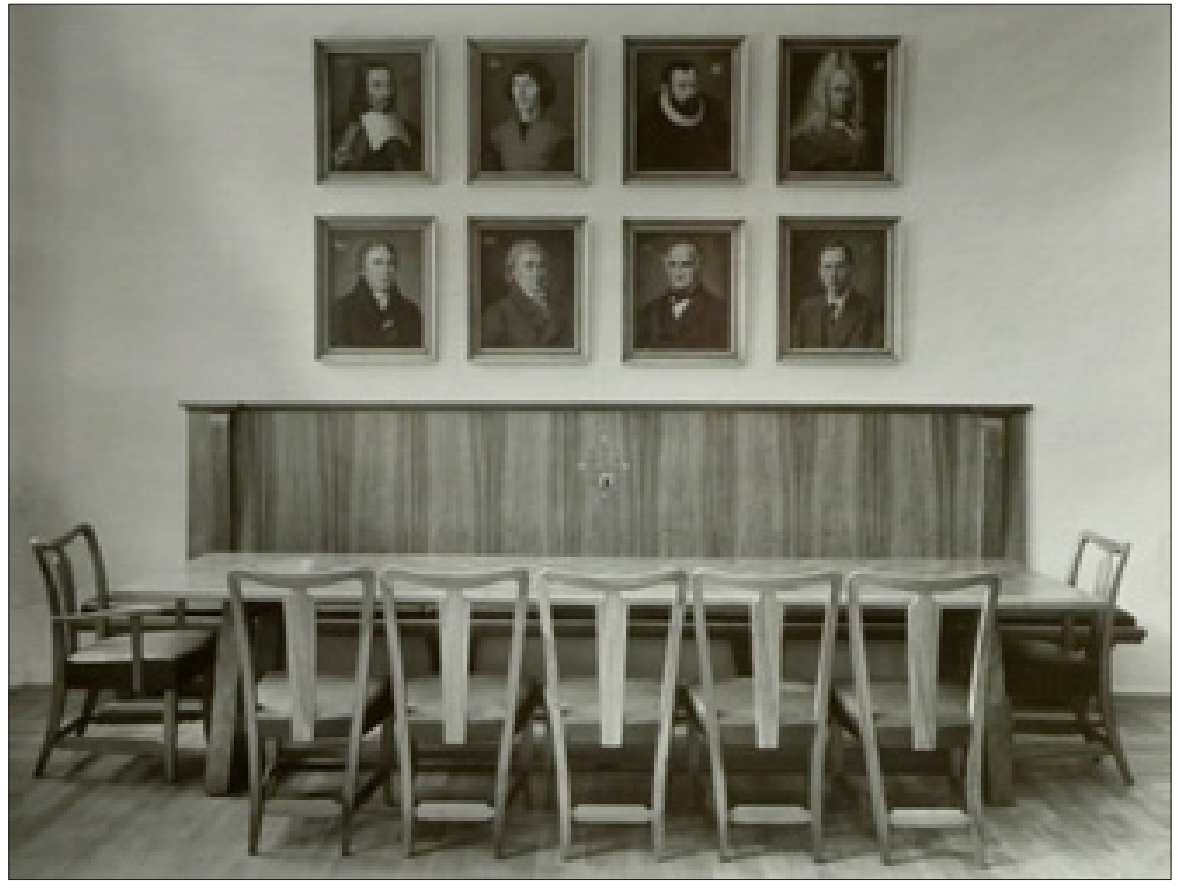

Il. 11. Kopie portretów znanych torunian, pędzla Karla Hemmerleina (1896-1970), Ratusz Staromiejski, gabinet burmistrza (ob. Sala Królewska). Fot. Kurt Grimm, 1942.

Fot. Muzeum Okręgowe w Toruniu.

Od lewej: Hermann Balk, Mikołaj Kopernik, Heinrich Stroband, Johann Gottfried Rösner, niezidentyfikowany, Samuel Thomas Sömmerring, Bogumil Goltz, niezidentyfikowany 


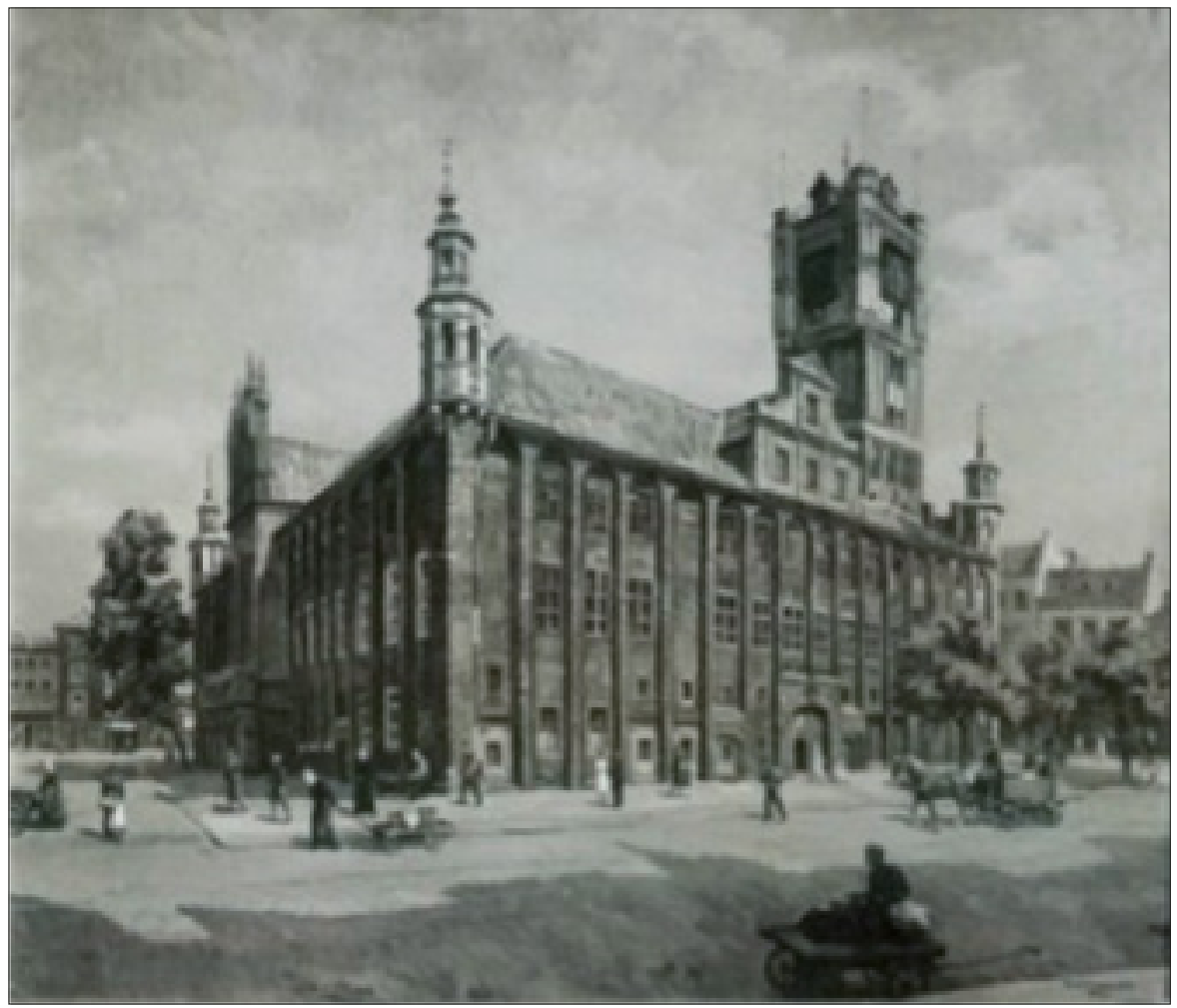

Il. 12. Karl Hemmerlein (1896-1970), Ratusz. Staromiejski w Toruniu, 1942, sygn. Fot. Kurt Grimm, 1942.

Fot. Muzeum Okręgowe w Toruniu 


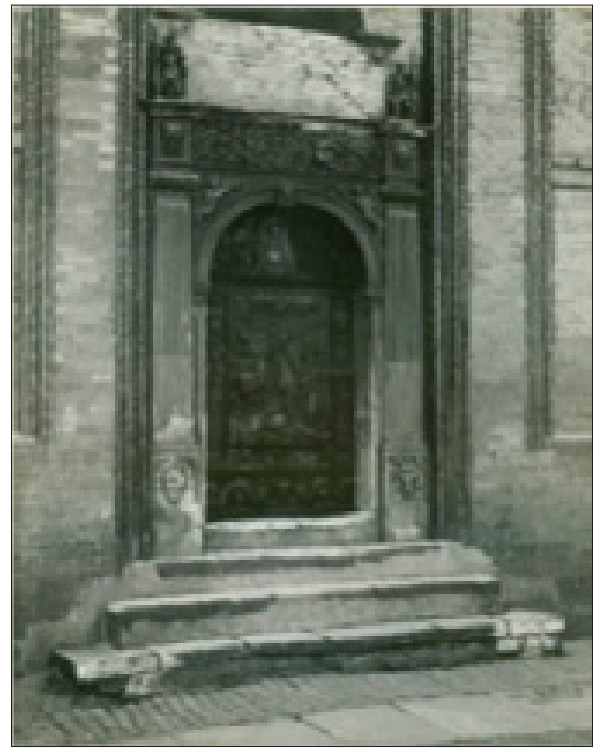

Il. 13. Hans Gebelein (1889-?), Portal Czerwonego Spichlerza pray ul. Laziennej 16 (Badergasse) w Toruniu, 1943, sygn. Fot. Kurt Grimm, 1942.

Fot. Muzeum Okręgowe w Toruniu 